PodBIELKowski Z. 1963. Notatki florystyczne z okolic Warszawy. Część IV. - Fragmenta Floristica et Geobotanica 9(4): 383-386.

PODBIELKOwSKI Z. 1967. Zarastanie rowów melioracyjnych na torfowiskach w okolicach Warszawy. - Monographiae Botanicae 23(1): 1-171.

Rostafiński J. 1873. Florae Polonicae Prodromus. Übersicht der bis jetz im Königreiche Polen beobachteten Phanerogamen. - Verhandlungen der kaiserlich-königlichen zoologisch-botanischen Gesellschaft in Wien (Jahrgang 1872) 22: 81-208.

RozPorZADZENIE Ministra Środowiska z dnia 9 października 2014 r. w sprawie ochrony gatunkowej roślin (Dz. U. z 2014 r., poz. 1409).

SudnIK-Wóscikowska B. 1987. Flora miasta Warszawy i jej przemiany w ciągu XIX i XX wieku. Część 2. Dokumentacja. s. 242. Wydawnictwo Uniwersytetu Warszawskiego, Warszawa.

SZYMCZYK T. 1984. Flora i walory przyrodnicze rezerwatu „Torfy” oraz zespołu bagienno-wydmowego między wsiami Śródborów i Jabłonka. Mskr. pracy magisterskiej. Instytut Botaniki Uniwersytetu Warszawskiego, Warszawa.

ZAJĄC A. 1978. Atlas of distribution of vascular plants in Poland (ATPOL). - Taxon 27(5-6): 481-484.

ZAJĄC A. \& ZAJĄC M. (red.). 2001. Atlas rozmieszczenia roślin naczyniowych w Polsce. s. xii + 716. Nakładem Pracowni Chorologii Komputerowej Instytutu Botaniki Uniwersytetu Jagiellońskiego, Kraków.

ZARĘBA R. 1984. Rezerwat przyrody „Grądy Celestynowskie”. Mskr. Katedra Urządzania Lasu i Geodezji Leśnej Szkoły Głównej Gospodarstwa Wiejskiego Akademii Rolniczej, Warszawa.

ZIELONY R. \& ŁASZEK CZ. 1995. Kolejne rezerwaty przyrody w województwie warszawskim. - Chrońmy Przyrodę Ojczystą 5(5): 85-88.

Pawee Pawlikowski, Zakład Ekologii Roślin i Ochrony Środowiska, Instytut Botaniki, Wydziat Biologii, Centrum Nauk Biologiczno-Chemicznych, Uniwersytet Warszawski, ul. Żwirki i Wigury 101,02-096 Warszawa, Polska; e-mail p.pawlikowski@uw.edu.pl

Wptynęto: 02.11.2019 r.; przyjęto do druku: 30.11.2020 r.

DOI: https://doi.org/10.35535/ffgp-2020-0037

\title{
Flora roślin naczyniowych rezerwatu Tobolinka w Puszczy Augustowskiej
}

Rezerwat Tobolinka położony jest na terenie Nadleśnictwa Pomorze w Puszczy Augustowskiej, w gminie Giby, powiecie sejneńskim i województwie podlaskim. W podziale fizyczno-geograficznym Polski (KONDRACKI 2002) teren ten leży w granicach mezoregionu Pojezierze Wschodniosuwalskie i makroregionu Pojezierze Litewskie. Rezerwat położony jest w kwadracie GB11 kartogramu Atlasu rozmieszczenia roślin naczyniowych w Polsce (ATPOL; ZAJĄC 1978).

Rezerwat Tobolinka utworzony został w 1959 r. „w celu zachowania jeziora dystroficznego z pływającymi wysepkami pła torfowców", a jego powierzchnia wynosi 4,62 ha. Pierwotnie wodno-torfowiskowy, obecnie klasyfikowany jest jako wodny, fitocenotyczny. Obejmuje śródleśne obniżenie bezodpływowe z niewielkim jeziorkiem (o powierzchni 
3,12 ha, głębokości maksymalnej 8,5 m i głębokości średniej 4,3 m) wraz z otaczającym, wąskim płem mszarnym, borem bagiennym oraz niewielkimi fragmentami borów wilgotnych i świeżych.

$\mathrm{Na}$ terenie rezerwatu stwierdzono dotychczas 32 gatunki roślin naczyniowych (SoKoŁOWSKI 2010), przy czym tylko kilkanaście taksonów zostało w cytowanym opracowaniu wymienionych z nazwy, a we wcześniejszym opracowaniu SoKOŁOwSKIEGO (2006) - zaledwie siedem.

Spis flory rezerwatu Tobolinka przeprowadzony został w lipcu 2016 i lutym 2020 r. W trakcie prac terenowych zweryfikowano istniejące dane florystyczne dotyczące rezerwatu (SoKoŁowski 2010). Nazwy taksonów przyjęte zostały za MiRKIEM i in. (2002). Lista gatunków zawiera informacje o obfitości występowania (I - pojedynczo; II - nielicznie; III - średnio licznie; IV - licznie; V - gatunek występujący bardzo licznie) oraz warstwach, w których zostały stwierdzone gatunki drzew i krzewów ( $\mathrm{a}_{1}-$ wyższa warstwa drzew; $\mathrm{a}_{2}$ - niższa warstwa drzew; b - warstwa krzewów - między 1,5 a 5 m wysokości; c - warstwa ziół).

Lista Gatunków: Agrostis canina II, Andromeda polifolia V, Betula pendula c, b, a $\mathrm{a}_{1}, \mathrm{a}_{2} \mathrm{IV}$, B. pubescens c, b, $\mathrm{a}_{1}, \mathrm{a}_{2}$ III, Calluna vulgaris III, Carex canescens II, C. digitata I, C. echinata II, C. lasiocarpa IV, C. limosa III, C. nigra III, C. pilulifera I, C. rostrata III, Comarum palustre IV, Convallaria majalis I, Corylus avellana c I, Deschampsia flexuosa II, Drosera rotundifolia III, Empetrum nigrum II, Eriophorum angustifolium IV, E. vaginatum IV, Festuca ovina I, Frangula alnus c, b III, Goodyera repens I, Juniperus communis c, b I, Ledum palustre V, Luzula pilosa I, Lysimachia thyrsiflora III, Melampyrum pratense II, Menyanthes trifoliata III, Molinia caerulea III, Monotropa hypopitys I, Oxycoccus palustris V, Peucedanum palustre III, Picea abies c, b, $\mathrm{a}_{2}$ IV, Pinus sylvestris c, b, $\mathrm{a}_{1}, \mathrm{a}_{2} \mathrm{~V}$, Populus tremula c I, Pteridium aquilinum s. lato III, Quercus robur c, b, $\mathrm{a}_{1}$ III, Q. rubra c I, Rhynchospora alba IV, Salix cinerea c II, Scheuchzeria palustris III, Scorzonera humilis I, Sorbus aucuparia c, b II, Vaccinium myrtillus V, V. uliginosum IV, V. vitis-idaea IV.

Na terenie rezerwatu Tobolinka stwierdzono występowanie zaledwie 48 gatunków roślin naczyniowych, co wynika z bardzo niewielkiego zróżnicowania siedlisk i ich oligotroficznego charakteru. Pośród nich jest pięć gatunków umieszczonych na polskiej „czerwonej liście" roślin naczyniowych (KAźMIERCZAKOwa i in. 2016): Carex limosa, Drosera rotundifolia, Goodyera repens, Rhynchospora alba i Scheuchzeria palustris, oraz siedem gatunków objętych ochroną gatunkową (ROZPORZĄDZENIE 2014). Spośród gatunków obcych (MiREK i in. 2002) odnaleziono jedynie Quercus rubra. Najliczniej reprezentowane sa gatunki o pędach zdrewniałych (fanerofity i chamefity - 19 gatunków) i przedstawiciele rodziny Cyperaceae (11 gatunków). W porównaniu z danymi prawdopodobnie z początku lat 90. XX w. (SoкоŁOwSKi 2006, 2010), w ciągu ostatniego ćwierćwiecza we florze naczyniowej rezerwatu nie zaszły większe zmiany (stwierdzono jedynie 16 gatunków więcej), a jego szata roślinna wydaje się bardzo stabilna. Tym samym najwłaściwsza jest kontynuacja ochrony zachowawczej przyrody rezerwatu, polegającej na całkowitym braku ingerencji, z wyjątkiem usunięcia gatunku obcego - Quercus rubra - z rezerwatu i jego sąsiedztwa, a także ekspansywnej Padus serotina z otaczających zbiorowisk leśnych. Celowe byłoby powiększenie obszaru chronionego o fragmenty boru bagiennego pozostające poza jego granicami, a także - co postulował już SoKOŁOWSKI (2010) - o sąsiednie jeziorko humotroficzne (dystroficzne). 
Podziękowania. Dziękuję uczestnikom dziewiątego Studenckiego Obozu Botanicznego, zorganizowanego w Puszczy Augustowskiej w dniach 10-16 lipca 2016 r. w Gibach przez stowarzyszenie Centrum Ochrony Mokradeł, za udział w niniejszych badaniach.

Summary. Vascular plants of the Tobolinka Nature Reserve in the Augustów Forest. A detailed study of vascular plants in the Tobolinka Nature Reserve (Augustów Forest, NE Poland) was carried out in July 2016 and February 2020. The reserve covers a very small area, and the diversity of its plant communities is very low due to the high acidity of its habitats (extremely poor fen surrounding a small polyhumic lake; wet and mesic pine forest). Only 48 species were recorded, including five species red-listed nationally (e.g. Goodyera repens, Scheuchzeria palustris).

\title{
LITERATURA
}

Kaźmierczakowa R., Bloch-OrŁowska J., Celka Z., Cwener A., Dajdok Z., Michalska-Hejduk D., PAWLIKowski P., SzCZEŚniak E. \& ZiarneK K. 2016. Polska czerwona lista paprotników i roślin kwiatowych. s. 44. Instytut Ochrony Przyrody Polskiej Akademii Nauk, Kraków.

KondRaCKI J. 2002. Geografia regionalna Polski. s. 440. Wydawnictwo Naukowe PWN, Warszawa.

Mirek Z., Pięroś-Mirkowa H., Zając A. \& ZająC M. 2002. Flowering plants and pteridophytes of Poland. A checklist. - W: Z. MireK (red.), Biodiversity of Poland. 1, s. 1-442. W. Szafer Institute of Botany, Polish Academy of Sciences, Kraków.

RozPORZĄDZENIE Ministra Środowiska z dnia 9 października 2014 r. w sprawie ochrony gatunkowej roślin (Dz. U. z 2014 r., poz. 1409).

SokoŁowski A. W. 2006. Przyroda województwa podlaskiego i jej ochrona. s. 336. Łomżyńskie Towarzystwo Naukowe im. Wagów, Łomża.

SokoŁowski A. W. 2010. Puszcza Augustowska. s. 292. Centrum Informacyjne Lasów Państwowych, Warszawa.

ZAJAc A. 1978. Atlas of distribution of vascular plants in Poland (ATPOL). - Taxon 27(5-6): 481-484.

PaweŁ PawlikowsKi, Zakład Ekologii Roślin i Ochrony Środowiska, Instytut Botaniki, Wydziat Biologii, Centrum Nauk Biologiczno-Chemicznych, Uniwersytet Warszawski, ul. Żwirki $i$ Wigury 101,02-096 Warszawa, Polska; e-mail p.pawlikowski@uw.edu.pl

Wptynęto: 25.02.2020 r.; przyjęto do druku: 17.12.2020 r.

DOI: https://doi.org/10.35535/ffgp-2020-0038

\section{Nowe stanowisko Botrychium lunaria (Ophioglossaceae) w Krakowie na tle danych historycznych}

\author{
Botrychium lunaria (L.) Sw., podejźrzon księżycowy, jest gatunkiem o zasięgu cyrkumbo- \\ realnym (ZAJĄC \& ZAJĄC 2009), najczęściej spotykanym przedstawicielem rodzaju Botry- \\ chium Sw. (Ophioglossaceae) w Polsce. W związku z obserwowanym spadkiem liczby \\ stanowisk w ostatnich dziesięcioleciach gatunek zaliczony został do narażonych we florze \\ Polski (ZARZYCKI i in. 2002; ZARZYCKI \& SZELĄG 2006; KAŹMIERCZAKOWA i in. 2016),
}

